\title{
ACUTE DIARRHOEA ASSOCIATED WITH CRYPTOSPORIDIUM SP \\ IN BELÉM, BRAZIL \\ (PRELIMINARY REPORT]
}

Edvaldo Carlos Brito LOURErRo (1), Alexandre da Costa LINHARES (1) \& Leonardo MATA (2)

\section{S U M M A R Y}

Cryptosporidium sp was detected in faeces from three children suffering from acute diarrhoea. In two cases no other concomitant agents were detected and in a 3rd. this agent was associated with Entamoeba histolytic, Entamoeba coli, EndoJimax nana, Chilomastix mesnili and Pentatrichomonas hominis.

KEY WORDS - Cryptosporidium sp - Acute diarrhoea.

Cryptosporidium sp, a coccidian parasite, belongs to family Cryptosporidiidae, suborder Eimeriorina. It was firstly detected by TYZZER ${ }^{13}$ in 1907 and has recently been described as potentially important enteropathogen, affecting both children and adults throughout the world $3,4,6,15,16$. This parasite has also been found infecting a wide variety of animals $2,7,14$.

Recent data on Cryptosporidium infection in humans have been obtained from studies carried out in population groups of Costa Rica ${ }^{9}$ and Venezuela 11 where it occurs more frequenty during the warmer, rainy and humid months of the year (May-August). It may also cause severe disease in patients whose immunity has been affected 12,17,18 and is a common finding among homosexual patients with AIDS (acquired im munodeficiency syndrome) $1,8,10$.

In our study, specimens were obtained from 61 children (1-2 years old) who were followed for 9 months, and who belong to a low socio economic area of Belém, Brazil. 150 Faecal samples were obtained, 94 from diarrhoeic patients and 56 from non diarrhoeic control patients.
The detection of Cryptosporidium was by a modified Ziehl-Neelsen staining ${ }^{5}$, as illustrated in Fig. $1 \mathrm{~A}$, which allows a presumptive diagnosis. Confirmation was by both Giemsa (Fig. 1B) and Auramine.rhodamine staining methods. The specimens were also processed for Salmonella, Shigella and Escherichia coli (classic serotypes, enteroinvasive and enterotoxigenic strains), and for rotaviruses, enteroviruses and adenoviruses. Faeces were also examined for intestinal para. sites.

Cryptosporidium was found in three $(3.19 \%)$ of the 94 samples. In two cases (specimen numbers 24.168 and 23.997) this was the only pathogen found, while in the 3rd. (number 24.004) it was associated with Entamoeba histolytica, Entamoeba coli, Endolimax nana, Chilomastix mesnili and Pentatrichomonas hominis. All non diarrhoeic control patients were negative for Cryptosporidium.

Our findings suggest that Cryptosporidium may be a causative agent of diarroea among children, since no viruses or enteropathogenic bacteria were detected in any of these cases. We would also like to stress that this is the

(1) Instituto Evandro Chagas, Fundação Serviços de Saúdt. Pública, Ministério da Saúde, Ca1xa Postal 621 - 66.000 , Belém, PA, Brasil

(2) Instituto de Investigaclones en Salud (INISA), Ciudad Universítária "Rodrigo Faclo", Universidad de Costa Rica Costa Rica 
LOUREIRO, E. C. B.; LINHARES, A. da C. \& MATA, L. - Acute d.arravea associated with Cryptosporidium sp in Belém, Brazil. Rev. Inst. Med, trop. Sio Paulo, 28:138-140, 1986.
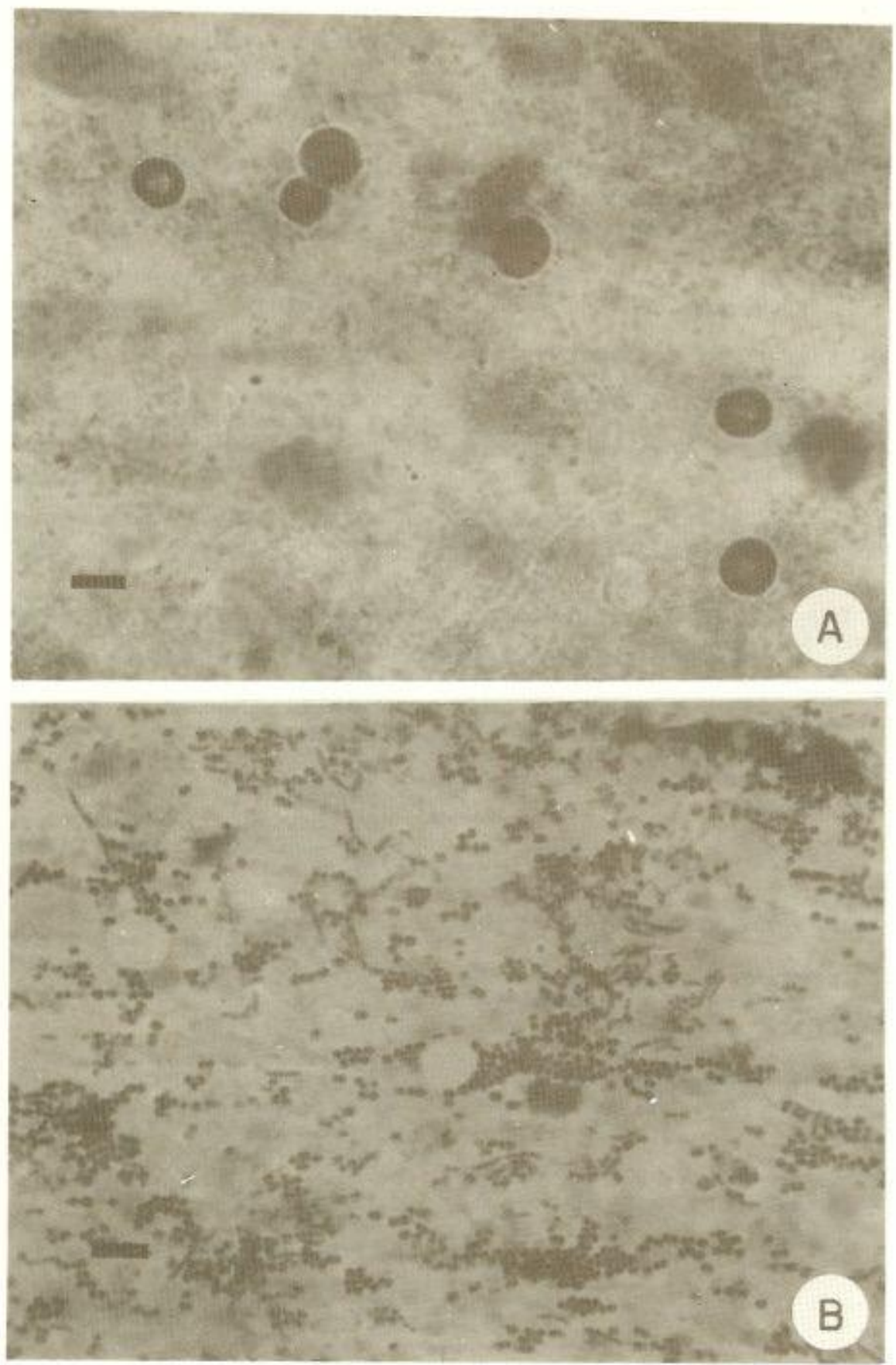

Pig. 1 - Cryptosporidium oocysts recovered from stool material and stained by the modified Ziehl-Neelsen (in $\mathrm{A}$, bar $=4 \mu \mathrm{m}$ ) and Giemsa (in $\mathrm{B}$, bar $=4 \mu \mathrm{m}$ ) methods

first time that this agent has been detected among patients with diarrheal syndromes in the Amazon region. Additional studies are required in order to elucidate epidemiological aspects of Cryptosporidium infection in our region.

\section{RESUMO}

Diarréia aguda associada a Cryptosporidium sp em Belém, Brasil

(Nota prévia) 
LOUREIRO, E. C. B.; LINHARES, A. da C. \& MATA, L. - Acute diarrhoea associated with Cryptosporidium sp in Belém, Brazil. Rev. Inst. Med. trop. São Paulo. 28:138-140, 1986.

Amostras de Cryptosporidium sp foram detectadas das fezes de três crianças com diarréia aguda. Em dois casos nenhum outro agente foi registrado, concomitantemente, e no terceiro caso, esse coccidio estava associado com Entamoeba histolytica, Entamoeba coli, Endolimax nana, Chilomastix mesnili e Pentatricho. monas hominis.

\section{REFERENCES}

1. ANDREANI, T.; MODIGLIANI, R.; LE CHARPENTIER, Y.; GALIAN, A.; BROUET, J. C.; LIANCE, M.; LACHANCE, J. R.; MESSING, B. \& VERNISSE, B. Acquired immunodeflciency with intestinal cryptosporidiosis: possible transmission by Haitian whole blood. Lancet, 1: 1187-1191, 1983.

2. ANGUS, $\mathrm{X}$. W. - Cryptosporidiosis in man, domestic animals and birds: a review. J. roy. Soc. Med., 76: 62-70, 1983.

3. CASEMORE, D. P. \& JACKSON, B. - Sporadic cryptosporidiosis in children. Lancet, 2: 679, 1983.

4. CURRENT, W. L.; REESE, N. C.; ERNST, J. V.; BAILEY, W. S.; HEYMAN, M. B. \& WEINSTEIN, W. M. - Human cryptosporidiosis in immunocompetent and immunodeficient persons: studies of an outbreak and experimental transmission. New Engl. J. Med., 308: 1252-1257, 1983.

5. GARCIA, L. S.; BRUCKNER, D. A.; BREWER, T. C. \& SHIMIZU, R. Y. - Techniques for the recovery and identification of Cryptosporidium oocysts from stool specimens. J. clin. Mìcrobiol., 18: 185-190, 1983.

6. HOJLYNG, N.; MOLBAK, K.; JEPSEN, S. \& HANS SON, A. P. - Cryptosporiidosis in Liberian children. Lancet, 1: 734, 1984.

7. ISEKI, M. - Cryptosporidium felis sp n. (Protozoa: Eimeriorina) from the domestic cat. Jap. J. Paxasit., 28: 285-307, 1979 .

8. MA, P. \& SOAVE, R. - Three-step stool examination for cryptosporidiosis in 10 homosexual men with protracted watery diarrhea. J. infect. Dis., 147: 824-828, 1983.
9. MATA, L.; BOLAÑOS, H.; PIZARRO, D. \& VIVES, M. - Cryptosporidiosis in children from some highland Costa Rica rural and urban areas. Amer. J. trop. Med. Hyg., 33: 24-29, 1984.

10. PAYNE, P.; LANCASTER, L. A.; HEINZMAN, M. \& MCCUTCHAN, J. A. - Identification of Cryptospor1dium in patients with the acquired immunodeficiency syndrome. New Engl. J. Med., 309: 613.614, 1983.

11. PEREZ-SCHAEL, I.; BOHER, Y.; PEREZ, M.; TAPIA, F, J. \& MATA, L. - Cryptosporidiosis in Venezuelan chlldren with acute diarrhea. Amer. J. trop. Med. Hyg. (in press, 1985).

12. STEMMERMANN, G. N.; HAYASHI, T.; GLOBER, G. A.; OISHI, N. \& FRANKEL, R. I. - Cryptosporidiosis: report of a fatal case complicated by disseminated toxoplasmosis. Amer. J. Med., 69: 637-642, 1980.

13. TYZZER, E. E. - A sporozoan found in the peptic glands of the common mouse. Proc. Soc. exp. Biol. (N.Y.), 5: 12-13, 1907.

14. TZIPORI, S. - Cryptosporidiosis in animals and humans. Microbiol. Rev., 47: 84-96, 1983.

15. TZIPORI, S.; ANGUS, K. W.; GRAY, E: W. \& CAMP. BELL, I. - Vomiting and diarrhea associated with cryptosporidial infection. New EngI. J. Med, 303: $818,1980$.

16. TZIPORI, S.; SMITH, M.; BIRCH, C.; BARNES, G. \& BISHOP, R. - Cryptosporidiosis in hospital patients with gastroenteritis. Amer. J. trop. Med. Hyg., 32: 931-934, 1983.

17. WEINSTEIN, L.; EDELSTEIN, S. M.; MADARA, J L.; FALCHUK, K. R.; MCMANUS, B. M. \& TRIER, J. S. - Intestinal cryptosporidiosis complicated by disseminatsd cytomegalovirus infection. Gastroenterology, 81: 584-591, 1981.

18. WEISBURGER, W. R.; HUTCHEON, D. F.; YARDLEY J. H.; ROCHE, J. C.; HILLIS, W. D. \& CHARACHE. P. - Cryptosporidiosis in an immunosuppressed renal transplant recipient with IgA deficiency. Am. J. clin. Path., 72: 473-478, 1979.

Recebido para publicação em 19/3/1985. 